\title{
MULTICULTURALISM AND SUBCULTURAL IN INDONESIA GENERAL ELECTION 2019
}

\author{
Riswandi ${ }^{1}$, Farid Hamid ${ }^{2}$, dan Sofia Aunul ${ }^{3}$ \\ Universitas Mercu Buana \\ Email : riswandi@mercubuana.ac.id
}

Keyword :

cross cultural

communication,

cultural values,

cultural perceptions,

subcultural.

DOI :

10.30595/jssh.v3i2.4979

\begin{abstract}
The issues of multiculturalism and subcultural are developing in the events of the Indonesian elections in 2019 such as democracy, equality in the fields of law, social, political, and cultural, human rights, honesty, justice, political choice, and unfair legal enforcement, so that people tend to split. The problem of this research is what are the cultural perceptions of the Jakarta multicultural community towards the events of the 2019 Election? The case studied was 2019 Election and primary data was obtained through interviews with 8 informants from the Javanese, Sundanese, Bugis, Chinese, Batak and Betawi subcultures, then confirmed by intercultural communication experts, Alo Liliweri. Data were analyzed using Miles and Huberman models which included data reduction, data display, and conclusion drawing / verification. The results showed that the cultural perceptions of the Jakarta multicultural community was based on subcultural perceptions, in which the Javanese, Batak and Chinese subcultures tended to support Jokowi-Maruf Amin, while the Sunda, Betawi, and Bugis subcultures tended to support Prabowo-Sandiaga. Nonverbal behavior of subcultural members regarding 2019 elections is oriented towards Dominant Culture or Indonesian National Culture as part of Eastern Culture, and is also influenced by their family background, profession and personal character.
\end{abstract}

\section{INTRODUCTION}

In the 2019 general election in Indonesia, the public discussed multiculturalism and subcultural issues, namely democracy, equality in the legal, social, political and cultural fields, human rights issues, honesty, justice, and the issue of law enforcement that is still "sharply down blunt upwards ". These problems arise because the Indonesian people are factually a pluralistic society, while some of the community groups, including participants in the 2019 election, feel that the government has not accommodated their aspirations.

In addition, the 2019 election was relatively different compared to the previous elections, where in this election there were frictions occurred based on religion, ethnicity, culture, gender, regionalism, and psychological factors, and political choices (Editorial, One Hope: January 12, 2017). This frictions not only hit the grassroots community, but also hit elite groups, including political party elites.

Some indications prove that there were already conflicts in the society by the appearance of some terms in mainstream media and social media that seem to represent two camps of two presidential / vice presidential in the 2019 elections such as "religious detractors", "Cebong versus kampret", "mukidi", "chubby face", "sontoloyo", genderuwo ". According to Saeful Mujani Research \& Consulting (SMRC), Saidiman Ahmad, terms like this 
can divide the nation (Republika.co.id, October 12, 2018). In addition, a lot of information circulating in the community as seen on social media, contains lies / "hoaxes". Social symptoms and terms like this have never appeared in previous elections in Indonesia.

The Prabowo - Sandiaga camp stated that the 2019 election considered dishonestly and unfairly as mandated by law, so they sued Jokowi - Ma'ruf Amin's victory, even though the lawsuit was finally rejected by the Constitutional Court Judges.

The issues of injustice and dishonesty in the electoral process apparently overlap with other issues related to subcultural and multiculturalism, while at the same time also raising the demands and aspirations of marginalized groups such as lesbian, gay, bisexual, and transgender people. , as well as group, regional or tribal aspirations. The fact also shows that there are a number of areas where Prabowo - Sandiaga has absolute wins such as Aceh, Riau, West Sumatra, South Sumatra, DKI, Banten, West, and West Nusa Tenggara, while on the other hand, Jokowi - Ma'ruf Amin wins absolutely in Central Java, East Java, East Nusa Tenggara (NTT), and Papua.

\section{METHOD}

The method of this research is descriptive with the technique of collecting data through interviews and observations of 8 key informants of the residents of Jakarta who have different cultural backgrounds (subcultures), namely from the Javanese ethnic group (2 people); Batak (1); Sunda (1); Bugis (1); Betawi (1); and Chinese (2).

The criteria or characteristics of key informants are as follows:

1. Know about the 2019 Election

2. Above 30 years old

3. Residing in Jakarta
To sharpen the results of research from the perspective of intercultural communication, researchers will confirm the results of research on an academic, namely Prof. Dr. Alo Liliweri, MS.

Data were analyzed using interactive models Miles and Huberman, which stated that there was an interactive nature between data or data collection and data analysis including data reduction, data display, and conclusion drawing / verification (Sugiyono: 2009).

\section{RESULTS AND DISCUSSION}

\subsection{RESULTS}

\subsubsection{Attention and Knowledge of the Subculture Society towards the Candidates / Vice-Presidents}

Based on interviews with informants at different times and places, all informants know and pay attention to information about the names and figures of the presidential / vice presidential candidates in the 2019 Election, as well as the names of legislative candidates (although the latter are not all exactly known) This is said among others by the following sources:

"I know and pay attention to the name of the 01 presidential and vice presidential candidate, namely Jokowi-Ma'ruf Amin and Vice President / Vice-President 02, namely Prabowo Subianto-Sandiaga Uno. I get this info from mainstream media such as television, as well as social media. In fact, I also know and pay attention to the characteristics of these two partners, namely if Jokowi is thin, speaks quietly, incumbents, then Prabowo is well-built, passionate, firm and nominates three times as presidential candidate ... My candidates know from the media, from neighbors, and there is someone I know directly (Interview with Ombun Suryono Sidauruk / Batak, Monday April 222019 and Mulyanto / Chinese, Saturday, May 4, 2019). 
Other speakers said the same thing about their attention and knowledge regarding the figures of presidential and vice presidential candidates 01 and 02 , as well as legislative candidates:

"The presidential candidate 01 has a simple character, a former mayor of Solo, likes to be blunt, his image is good, and his style of speech is rather slow, while the presidential candidate 02 is disciplined because his background is military, Soeharto's daughter-in-law, brave, emotional, like if there is a problem ... DKI Jakarta DPRD I know H. Taufik from Gerindra, others only know at a glance, Rano Karno from PDIP Banten, H. Abdullah from Nasdem (Interview with Dedi Damhudi / Sunda, Tuesday, April 23, 2019 and Bondan / Java, Tuesday, April 23 2019).

Regarding the program or vision socialized by the Presidential Candidates 01 and 02 there was an interesting finding from Chinese ethnic informant knew more about the Presidential Candidate 01 program than the Presidential Candidate 02 program / vision, as they said, "Program 01 is KJP, infrastructure, Healthy Cards, while program 02 I don't remember their program "(Interview with Mulyanto / Tionghoa, Saturday, May 4, 2019 and Puspita Hanny / Chinese, Saturday, May 4, 2019).

Based on the sensations and attention of the informant about the presidential and vice presidential candidates 01 and 02 and legislative candidates.

"My perception of the presidential candidate 01 is clean, honest, populist, family background is not problematic, while my perception of presidential candidate 02 is persistent, resilient, never giving up, cool or at least wanting to portray himself like that (interview with Ombun Sidauruk, Monday, April 22, 2019) ... "My perception of the presidential candidate 01 was an experienced president because now as a incumbent, so knowing the ins and outs of governance in the presidential environment, while my perception of Presidential Candidate 02 was disciplined, courageous to make decisions, not easily controlled, tended to be authoritarian, and sometimes this country really needs people who are authoritarian or strong people "(interview with Ridho Azlam / Bugis, Tuesday, April 30, 2019).

\subsubsection{Perception of Subculture} Communities on 2019 Elections

\section{a. Chinese Subculture}

Puspita Hanny as informant states

In my opinion, human relations with God are how we behave towards the people around us. For example, I am a Buddhist, in my religion, God is formless, invisible, how we behave to parents is the same as we respect God. When I respect parents, that means I respect God. So if I respect parents, I respect God. Likewise another example, respecting teachers, both spiritual and academic education, yes like that ... In the context of relationships with other people, when I socialize with other people, it cannot be separated from the guidance of religion ... as well as maintaining good relationship, because we need each other, like my relationship with my pet. Why? Because in our religion, we are taught to do good, there is compassion, love, how we treat the animal best. We must treat dog well ... there are guards and then demeaned "(Interview with Puspita Hanny / Tionghoa, Saturday, May 4, 2019).

When Puspita Hanny asked the following question, "Does the understanding of the cultural or Buddhist values mentioned above affect the assessment of the phenomenon of the 2019 Presidential Election? Puspita answers as follows

"Yes, there is an effect, in my opinion, when I first saw Ma'ruf Amin as Vice- 
President 01, he was wearing a sarong and all kinds of things, it was normal from his own culture. I then thought and raised a question in my heart, Why should Ma'ruf Amin be dressed like that, while other people are dressed well. But this is from the cultural thinking that I adhere to ... not from the culture of Ma'ruf Amin. Another example, I am with my friend from Jambi, I dress as usual, but my friend always wears a sarong, there is a purpose, and I agree because it is his habit and his experience is like that (Puspita Hanny, Ibid).

Mulyanto and Puspita Hanny then explained the true values of Chinese culture as follows:

"The true values of Chinese culture are based on the teachings of Confucius, namely 1) Not Desperate; Chinese ethics implies that fate can be changed by the person himself, through effort and effort, without despairing people will achieve success, 2) Advanced and Modern, Chinese Ethics in its concept encourages people to be reformist and dynamic, new innovations, product development, structuring storefront space, management renewal and systems, organizations must always change to a better direction, 3) Jien's concept, that Chinese Ethics believes that God created humans with genuine attitudes. Each part of the body and its role are bed linen of the original characteristics by God Almighty. But only a Prophet can use all that perfectly, 4) The Concept of Love, Chinese Ethics says that love is love of man, and he is a virtue or kindness that is reciprocal, 5) Decency or Lee, this involves many things such as tradition, institutions, written and unwritten laws, customs, and conventions, 6) Truth or Gie, a socially feeling person usually behaves wisely and frankly, he will say his opinion is simple about matters concerning the general good, and he will behave consistently with his opinion "(Interview with Mulyanto and Puspita Hanny, Ibid).
When asked Puspita Hanny the following questions, "did the understanding of the values of the culture or religion of Kong $\mathrm{Hu} \mathrm{Cu}$ influence the assessment of the phenomenon of the 2019 Presidential Election?

'In my opinion, the values of Chinese culture were influential when I observed the phenomenon of the 2019 Election, especially the presidential and legislative elections. In my opinion as part of Chinese ethnicity, for number 01 it seems he is trying not to harm many parties, and trying not to sacrifice much or be sacrificed ... whereas for number 02 I think maybe this side is less visible '(Puspita Hanny, Ibid) .

\section{b. Bugis Subculture}

The source from the Bugis tribes, Ridho Azlam, expressed his view of his culture as follows:

1) siri is a life view aimed at maintaining and improving dignity and self-esteem, both as individuals and as social creatures. Other cultural values inherent in Bugis sukubangsa are 2) Lempu meaning honest; 3) Getteng means firm, courageous and strong in planning; 4) Ada' Tongeng meaning 'hold on to truth'; 5) Temmapaisilaingeng which means' fair to all parties; 6) Pesse, defined as a subtle feeling in preserving the sense of unity in the grief and anguish of every member of the community; 7) Were or Sare, meaning that only by working hard without being bored can change one's fate "(interview with Ridho Azlam, Ibid).

Regarding the traits of a leader in Bugis or Makassar Culture is explained by Ridho as follows:

"The leader's philosophy is illustrated by the teachings of the lontara with one attitude, namely the Leadership of the Leader. This philosophy teaches that the identity of a leader with which he leads is not based on structural relations that rely on the hierarchy of positions based on the power, even the arrogance of the leader. But 
a believer must have a character who is wise and wise, have the sensitivity and responsiveness in understanding the dynamics of the people he leads "(Ridho Azlam, Ibid).

\section{c. Batak Subculture}

The informant from Batak ethnic group Ombun Suryono Sidauruk and regarding the values of this Batak culture, Ombun said as follows:

The cultural value that is the pride of the Batak ethnic group is Dalihan Na Tolu, which is a system of social relations in a very thick family relationship (genealogical) and marriage. This cultural value plays a role in regulating social relations among the three relatives functionally, namely the relatives of one tribe (dongan tubu), relatives of the recipient of the wife or what is called the term boru and relatives of the wife or known as hula-hula ... Dalihan na tolu in the system Batak culture is used as a living order and at the same time a source of motivation to behave. The cultural values of this to provide guidance for orientation, perception, and definition of reality ... Operationally the social relations that are built into the cultural system of transition are carried out in the form of careful behavior to relatives as high as or called manat mardongan tubu, persuading behavior to the recipient of the wife or known as elek marboru, and behaving in a prostrate manner to the wife of the giver or also said as somba marhula-hula "Then if asked to me, do I implement those cultural values in everyday life? So the answer is yes ... But I can't judge, who can judge is someone else, I can't judge myself. Later, if I say I carry out all of those values, it turns out that other people say no. So those who can judge are other people who interact with me as social beings (Interview with Ombun Suryono Sidauruk, Monday, April 22, 2019).
In Batak culture there are also cultural values that concern the criteria of a leader / king, as explained by Ombun Suryono, "The criteria for a leader in Batak culture is that he must be 1) Parbahul-bahul nabolon. Bahul means a large basket to store rice, rice or other crops. So the point is. the king / leader must be generous, serve and protect, a good listener, full of consideration, virtuous and with a great spirit; 2) Paramak Sobalunon, Amak is a mat made from pandan leaves which is usually held for guests who come. So Paramak sobalunon means the nature of a leader who is willing / open to accept the arrival of the people he leads. The character of the king must be populist, mingling with the people he leads; 3) Parsangkalan Somahiang. Disclaimer is a cutting board / wood foundation to chop meat. Parsangkalan Somahiang in leadership is defined as a leader who constantly sacrifices for the benefit of others. Can also be interpreted as a forgiving leader.4) Parpinggol Sohatuhilan, Pinggol means ear, So Parpinggol Sohatuhilan means a king who is not thin ears. It is not easy to believe in a one-sided report, let alone make conclusions and decisions without checking and rechecking. A prudent king in weighing a case "(Interview with Ombun Suryono Sidauruk, Ibid),

\section{d. Javanese Subculture}

According to Dianto Alif and Bondan as speakers representing Javanese Culture, the values of Javanese culture are as follows:

"1) Belief / perseverance, in Javanese society's thought, the planting of spiritual values in each of its actions becomes the main thing, because all things that occur in human life do not escape God's will; 2) Achievement (hopes and ideals), to achieve a purpose in life, it takes an effort that includes hard work and a request for God. The intended application is realized 
through several actions, namely prayer and practice. Prayer as the basic attitude of begging is a self-approach to the Creator so that one's wishes can come true. Laku is a form of application of prayer according to Javanese understanding, which emphasizes itself in the process of approaching God; 3) Patience, the emergence of patience according to Javanese ideology, recognize the existence of lust, nrimo, and patience. Rila, is the first step to consecrate the heart through happiness; Nrimo, emphasizes 'what is there' from factuality in life, accepts everything happily; Patience, is spaciousness that embraces all contradictions, 4) Harmony, Javanese ideology that always prioritizes harmony of life always encourages its people to strive for all forms of kindness and good relations with each other "(Interview with Bondan I Java, Tuesday, April 23, 2019 and Dianto Alif, Friday, April 26, 2019).

Regarding the characteristics or values of Javanese culture about leadership, explained by the two informants as follows: "1) Monocentrum, means that leadership is centered on a single figure. Javanese leadership is single, which is centered on one person. The disadvantage is, once a leader disappears, the existing system will experience chaos, 2) Metaphysics; that is always associated with metaphysical matters such as revelation, pulung, drajat, offspring, and so on. It's like the ability to lead a capability, but it tends to be a miracle. 3) Ethical, meaning what is desirable is something based on good bad, but the real application concept offered is not at all shown. In other words, the values conveyed are not accompanied by a kind of achievement method, 4) Syncretic, meaning the concepts taken are concepts originating from various religions which have an influence on the thinking in Java, especially Islam and Hinduism. thought Islam was usually adopted from Sufi teachings which put forward the aspect of wara (away from the luxury of the world) and simple life to lead a true life "(Dianto Alif and Bondan, Ibid).

\section{e. Sundanese Subculture}

Resource persons from the Sundanese ethnic group, Dedi Damhudi, said, The Sundanese cultural values regarding leaders and leadership are as follows:

"In Sundanese culture, a leader is defined as a center surrounded by followers. Relationships and leaders here are dependent relationships, where the center I leader has a higher position than his followers. The relations are both superiorinferior, the leader above and followers below. In Sundanese culture there are 10 characteristics that must be possessed by a leader or prospective leader called dasa pasanta, namely as follows: 1) For; meaning that the leader gives the understanding of the usefulness of his command to his subordinates so that there is a common perception, 2) Friendly; meaning that the commandment is delivered in a friendly and refined manner so that those who are governed feel valued as human beings, 3) Hookeun; it means that the confidence of the person being governed can be grown by respecting their creative achievements, 4) Pesok; meaning that leaders need to often conduct friendships to lure the hearts of those they lead and create feelings of calm, 5) Asih; it means that the person who is governed has a sense of responsibility, the leader must show affection to his subordinates, 6) because; meaning the leader of therus has compassionate nature and gives more value to his subordinates, 7) Mukpruk; meaning that leaders need to give trust to subordinates, so they feel valued in their abilities, 8) Ngulas; meaning that the leader is required to raise awareness to subordinates so that they do not carry out work because they are forced to, 9) Miserable; meaning the leader in criticizing the work of subordinates must 
be done in a way that is wise, thorough, and wise, 10) Ngala-angen; it means that the leader also needs to be stale to attract subordinate sympathies, for example by asking about family conditions. The ten characteristics can be said to be basic abilities that must be possessed by a leader or prospective leader (Interview with Dedi Damhudi, Tuesday, April 23, 2019 at Puspitek Serpong).

In addition, the culture also is a saying or proverb that the guidelines in the kepemimipinan the like, as follows:

1) "Sagolek pangkek, knot firmly, meaning that it is white and white, yes that is black is black. That is when the king had made keputusn, yes it is, can not be contested; 2) Ngadek sacekna nilas saplasna; means in terms of speaking, the king must be truthful and accurate; 3) Ulah dengdek topi; means a king, not actually in favor of one group or individual, but must be based on justice and truth; 4) Heunteu cueut kanu hideung, heunteu ponteng kanu koneng, not yellow canoe skipping; It means almost the same with dengdek topi, a king is not biased, but consistent in running the government on the principles of justice and truth "(Interview Damhudi Smith, ibid)

\section{f. Betawi Subculture}

M. Nasir as the informant explained about the views of the Betawi ethnic group regarding leaders and leadership as follows:

"Because Betawi culture is heavily influenced by Islam, the leadership values in Betawi culture are influenced by Islamic thought, namely 1) Siddiq; meaning honest, true, high integrity and awake from mistakes; 2) Fathonah, meaning intelligent, highly intellectual and professional; 3) Trustworthiness, meaning trustworthiness, legitimacy and accountability; 4) Tabligh, which means always conveying the minutes of truth, never hiding what must be conveyed, and communicative "(Interview with $M$. Nasir, Tuesday, April 23, 2019, at Puspitek LIPI Serpong)

Non-verbal Subculture Processes in the 2019 Election. The results of the study can be illustrated through the following table 1 :

Tabel 1. Illustration the results of the study

\begin{tabular}{|l|l|l|l|l|l|l|l|}
\hline No & $\begin{array}{l}\text { Nonverbal } \\
\text { Process }\end{array}$ & $\begin{array}{l}\text { Informant } \\
\text { profession }\end{array}$ & $\begin{array}{l}\text { Hand } \\
\text { shake }\end{array}$ & $\begin{array}{l}\text { Eye } \\
\text { contact }\end{array}$ & Proxemic & $\begin{array}{l}\text { Time } \\
\text { Perception }\end{array}$ & $\begin{array}{l}\text { Political } \\
\text { Preferen } \\
\text { ce }\end{array}$ \\
\hline 2 & Javanese & $\begin{array}{l}\text { Researcher } \\
\text { and } \\
\text { entrepreneur }\end{array}$ & Yes & $\begin{array}{l}\text { Yes, } \\
\text { sometime } \\
\text { s }\end{array}$ & $\begin{array}{l}\text { Apprepriatenes } \\
\text { sto culture and } \\
\text { situational } \\
\text { contextb }\end{array}$ & $\begin{array}{l}\text { valuable, } \\
\text { linear and } \\
\text { sometimes } \\
\text { circular }\end{array}$ & $\begin{array}{l}\text { Pro } \\
\text { Jokowi }\end{array}$ \\
\hline 3 & Sundanese & researcher & Yes & $\begin{array}{l}\text { Yes, } \\
\text { sometime } \\
\text { s }\end{array}$ & $\begin{array}{l}\text { Apprepriatenes } \\
\text { sto culture and } \\
\text { situational } \\
\text { context }\end{array}$ & $\begin{array}{l}\text { valuable, } \\
\text { linear and } \\
\text { sometimes } \\
\text { circular }\end{array}$ & $\begin{array}{l}\text { Pro } \\
\text { Prabowo }\end{array}$ \\
\hline 4 & Batak & Lawyer & Yes & Yes, often & $\begin{array}{l}\text { Apprepriatenes } \\
\text { sto culture and } \\
\text { situational } \\
\text { context }\end{array}$ & $\begin{array}{l}\text { valuable, } \\
\text { linear and } \\
\text { sometimes } \\
\text { circular }\end{array}$ & $\begin{array}{l}\text { Pro } \\
\text { Jokowi }\end{array}$ \\
\hline & Betawi & Researcher & Yes & Yes, often & $\begin{array}{l}\text { Apprepriatenes } \\
\text { sto culture and } \\
\text { situational } \\
\text { context }\end{array}$ & $\begin{array}{l}\text { valuable, } \\
\text { linear and } \\
\text { sometimes } \\
\text { circular }\end{array}$ & $\begin{array}{l}\text { Pro } \\
\text { Prabowo }\end{array}$ \\
\hline
\end{tabular}




\begin{tabular}{|l|l|l|l|l|l|l|l|}
\hline 5 & Bugis & Lecturer & Yes & Yes, often & $\begin{array}{l}\text { Apprepriatenes } \\
\text { s culture and } \\
\text { situational } \\
\text { context }\end{array}$ & $\begin{array}{l}\text { valuable, } \\
\text { linear } \\
\text { sometimes } \\
\text { circular }\end{array}$ & $\begin{array}{l}\text { Pro } \\
\text { Prabowo }\end{array}$ \\
\hline 6 & Chinese & $\begin{array}{l}\text { Teacher and } \\
\text { entepreneur }\end{array}$ & Yes & $\begin{array}{l}\text { Yes, } \\
\text { sometime } \\
\text { s }\end{array}$ & $\begin{array}{l}\text { Apprepriatenes } \\
\text { s culture and } \\
\text { situational } \\
\text { context }\end{array}$ & $\begin{array}{l}\text { valuable, } \\
\text { linear and } \\
\text { circular }\end{array}$ & $\begin{array}{l}\text { Pro } \\
\text { Jokowi }\end{array}$ \\
\hline
\end{tabular}

\subsection{DISCUSSION}

Subcultural relatively high attention to the phenomenon of the 2019 Election. This can be seen from their knowledge and understanding of the names of Presidential and Vice-Presidential Candidates 01 and 02, names of candidates, as well as programs or visions of these two candidates.

Belief system. attitudes, worldview, and perceptions of the Jakarta subcultural community can be known after they communicate their views on aspects related to the 2019 Election.

The symbols, concepts, and categories contained in the culture of Jakarta's subcultural society are revealed when they perceive the phenomenon of the 2019 Election.

The concepts are Jien, love, Kesusilaan / Lee, truth / Gie (Chinese); Siri, Lempu, Getteng, Ada Tangeng, Pesse, and Were / Sare (Bugis); Dalihan $\mathrm{Na}$ Tolu, Dongan Tubu, Boru, Hula-hula (Batak); Belief, Achievement, Patience, and Harmony (Java); Useful, Friendly, Horokeun, Pug, Asih, Karunya, Mukpruk, Ngulas, Nyusep, and Ngala Angen (Sunda); and Siddiq, Fathonah, Amanah, and Tablig (Betawi).

Subcultural community members tend to be obedient and obey their cultural norms and values with motives to get appreciation from their culture. So here the process of encoding messages and emotional or evaluative meaning and the frame of reference of the participants of the communication takes place.
Subcultural communities pay relatively high attention to the phenomenon of the 2019 Election. This can be seen from their knowledge and understanding of the names of Presidential and Vice-Presidential Candidates 01 and 02, names of candidates, as well as programs or visions of these two candidates.

Belief system. attitudes, worldview, and perceptions of the Jakarta subcultural community can be known after they communicate their views on aspects related to the 2019 Election.

The symbols, concepts, and categories contained in the culture of Jakarta's subcultural society are revealed when they perceive the phenomenon of the 2019 Election.

The concepts are Jien, love, Decency / Lee, truth / Gie (Chinese); Siri, Lempu, Getteng, Ada Tangeng, Pesse, and Were / Sare (Bugis); Dalihan Na Tolu, Dongan Tubu, Boru, Hula-hula (Batak); Belief, Achievement, Patience, and Harmony (Java); Useful, Friendly, Horokeun, Pug, Asih, Karunya, Mukpruk, Ngulas, Nyusep, and Ngala Angen (Sunda); and Siddiq, Fathonah, Amanah, and Tablig (Betawi).

Subcultural community members tend to be obedient and obey their cultural norms and values with motives to get appreciation from their culture. So here the process of encoding messages and emotional or evaluative meaning and the frame of reference of the participants of the communication takes place.

Subcultural cultural perceptions can be seen from statements such as "the identity 
of a leader with whom he leads is not based on structural or hierarchical relations, but a leader must have a wise and wise character, sensitive and responsive in understanding the dynamics of the community he leads" (Bugis). Whereas in Javanese Culture there are monocentrum, metaphysical, ethical, and syncretic leadership values, and there are also cultural values about leadership which are symbolized into proverbs (Sundanese).

Family and school social organizations have an influence on the Jakarta multicultural community in responding to the 2019 Election phenomenon. The internalization process that they obtain in their families and schools results in thinking patterns and the ability to use language that is typical / typical of their ethnicity, where these individuals come from. This is evidenced by the unique terms of reference that belonged to the ethnic group which were spoken when they described what had happened.

The research results from the side of social organizations that underlie or guide the statements / communication of the speakers regarding the phenomenon of the 2019 Election are appropriate and strengthened by the results of research that focuses on verbal processes, namely those relating to thinking patterns and verbal language. This is in accordance with the theory in cross-cultural communication which states that, language is the main tool used by culture to channel knowledge / beliefs, values, and norms. Language is a tool for thinking and for interacting with people, without language people cannot th ink, and function as a mechanism for communication and guidelines for understanding social reality.

The members of the subculture also acknowledge that sometimes because of their profession and personal character, the factors that become the understanding of the culture are not always practiced. This is what the Batak people said by Ombun Suryono, that "I as a lawyer have never too kept a distance from my client, this is the demand of my profession that must be close to the person I want to help". Likewise, the observation of Puspita Hanny (Chinese) and Ridho Azlam (Bugis), both of them appear to be extroverted, so they are more open in answering each question, and "straight forward in communicating".

So, besides being obedient to cultural values and norms, members of the subculture are also pragmatic in practicing them in daily life. Therefore, it is only natural that today many regional subculture or cultural cultures in Indonesia are being eroded by the current of modernization. Children who are called millennial generation today have many who cannot speak the area where their parents come from.

The tendency of political choices of subculture members towards certain presidential / vice presidential candidates in the 2019 Election is in accordance with the guidance and demands of cultural values which later can influence the attitudes and policies of the winning presidential and vice presidential candidate. This proved to be true, not long after Jokowi - Ma'ruf Amin was declared victorious, Jokowi immediately said that he would prioritize development in areas where he was absolutely, namely Central Java, East Java, NTT, Bali, and Papua. The public will certainly interpret, other areas where he lost in absolute terms such as Aceh, West Sumatra, Riau, Banten, will not be noticed.

\section{CONCLUSION}

Based on the results of the research and discussion as stated in the previous section, conclusions can be drawn as follows: 
1. Members of the subcultural community pay attention and know the phenomenon of the 2019 Election which includes the Presidential Election and Legislative election.

2. The subcultural belief system, values, attitudes, and worldview guide and demand them in perceiving the phenomenon of the 2019 election. Javanese, Batak, and Chinese subcultural communication behaviors tend to support Jokowi, while subcultural Sundanese, Betawi, and Bugis tend to support Prabowo.

3. Experience in the family and school becomes the determining factor behind the subcultural members' political communication when perceiving the 2019 Election phenomenon.

4. Members of subcultural communities are able to use the regional language from which they come from, and through a typical thinking process they are able to interpret the phenomenon of the 2019 Election by using their regional language.

5. Nonverbal behavior of members of subcultural communities oriented toward of subcultural members focused on dominant culture or Indonesian National Culture as part of Eastern Culture, and were also influenced by the profession and personal character.

\section{REFERENCES}

Helmiaty, H, 2013, Dinamika Islam Singapura : Menelisik Pengalaman Minoritas Muslim di

Negara Singapura yang Sekuler \& Multikultural, dalam TOLERANSI, Jakarta.
Liliweri, Alo, 2009, Prasangka \& Konflik : Komunikasi Lintas Budaya Masyarakat Multikultur, LKIS, Yogyakarta.

Moleong, Lexy, 1998, Metodologi Penelitian Kualitatif, Remaja Rosda Karya, Bandung

Mulyana, Dedy \& Rahmat, Jalaludin, 2005, Komunikasi AntarBudaya, : Panduan Berkomunikasi dengan Orang-orang Berbeda Budaya, Rosdakarya, Bandung.

Nasikun, 2004, Sistem Sosial Indonesia, Rajawali Press, Jakarrta.

Rahmat, Jalaludin, 1998, Metode Penelitian Komunikasi, Rosda Karya, Bandung

Rahardjo, Mudji, 2012, Studi Kasus Dalam Penelitian Kualitatif :Konsep dan Prosedur, Universitas Islam Negeri Malang.

Samovar, Larry A, et.al, 2010, Edisi 7, Komunikasi Lintas Budaya : Communication Between

Cultures, Penerbit Salemba Humanika, Jakarta.

Sugiyono, 2009, Metode Penelitian Kuantitatif Kualitatif dan R \& D, Alfabeta, Jakarta.

Bernadette B, "Religi Orang Jawa" dalam Kompasiana.com, diunggah, 10 Juli 2019. 